\title{
Assessing the Communicative Use of Literary Texts in EFL Coursebooks
}

\author{
Shaima J. Al-Saeed ${ }^{1} \&$ Abdullah A. Alenezi ${ }^{1}$ \\ ${ }^{1}$ Language Center, Public Authority for Applied Education and Training, Kuwait \\ Correspondence: Abdullah A. Alenezi, Language Center, Public Authority for Applied Education and Training, \\ Kuwait. E-mail: aa.alenzi@paaet.edu.kw
}

\author{
Received: April 18, 2021 Accepted: May 20, 2021 Online Published: May 25, 2021 \\ doi:10.5539/ells.v11n2p68 URL: https://doi.org/10.5539/ells.v11n2p68
}

\begin{abstract}
Integrating and utilizing literary texts from coursebooks in foreign language teaching could impact the communicative competence of language learners. The study aims to scrutinize the usage of authentic and inauthentic literary texts found in 44 mainstream English as a foreign language (EFL) coursebooks. The article particularly examines how texts can facilitate communicative language learning and teaching in language classes. To do this, the study proposes a set of principles that can enable using literary texts more appropriately. The analysis of the study indicates that authentic and inauthentic literary texts are used differently, with authentic texts providing great opportunities for communication and offering a unique contribution to the EFL classroom. The study has implications for language teachers and coursebook designers in language programs. Further recommendations are made on how literature can be used communicatively.
\end{abstract}

Keywords: literary texts, EFL, coursebooks, CLT

\section{Overview}

Literature plays a major role in foreign language teaching, and this role has been different at different times. Literature was a vital source for foreign language learning classes when the grammar translation method of teaching was in vogue. However, with the shift to the direct method and then to situational language teaching, literature lost its central role and was even excluded from foreign language learning. With the rise of the communicative language teaching (CLT) method, along with its emphasis on including authentic texts, literature gradually returned to the scene in language learning.

A considerable body of research has been conducted on the use of literature in EFL classes and has highlighted its benefits for language learners. Thus, many scholars have recommended incorporating literary texts in English as a second language (ESL) classes. Regarding the position of literary texts in ESL classes, Khatib et al. (2011) provided an overview of their advantages and drawbacks. In a recent article, Ali et al. (2021) studied the use of poetry in ESL classrooms and found that it motivated learners to engage in extensive and intimate interactions with each other and thus increase their language fluency. In addition, poetry according to Imron and Hantari's (2021) study strengthens the writing skills of EFL learners via improving their creative thinking, motivation, and vocabulary learning. Similarly, Ashrafuzzaman et al. (2021) confirmed the significant effect of literature on developing learners' language skills. It enhances the learners' motivation. Mart (2016) explained that a reliance only on linguistic elements in ESL teaching hindered leaners' language fluency; the researcher concluded that observing the interactional exchanges among the characters in literary texts contributed to the development of ESL learners' communicative competence and language proficiency. The use of suitable literary texts in a language classroom, as explored by Violetta-Irene (2015), not only contributed to the overall learning experience but also offered learners a space in which to comment and reflect on themselves. Other studies have also shown the significant role literature can play in motivating foreign language learners (Khatib et al., 2011; Vural, 2013). Despite their benefits in foreign language teaching, literary texts are not used as often or as freely as they should be (Gumusok, 2013).

These studies have shown the advantages of using literature in classes. An important additional consideration is the way in which literature is used. Ideally, tasks should be realistic or transferable to real-life situations and should also elicit an authentic response. However, a recent study by Al-Saeed and Alenezi (2020) showed that recent popular EFL coursebooks continued to use inauthentic and poorly adapted literary texts. Therefore, it is 
important to consider the effect of such materials on coursebooks.

This is an area that requires further exploration since not much research has been conducted on this subject in general, and specifically in the middle east. It is a neglected area of study, especially in the Arab region, where it is of great significance as cultural awareness needs to be raised. Examining course books' use of literary texts concerning communicativeness is a step towards a better understanding of how authentic literature is used in this region, and hopefully would lead to recommendations on how to make use of these texts communicatively.

The researchers of the current study aim to assess how literary texts are used and the approaches in dealing with them by focusing on the following objectives:

1) Comparing the usages of authentic and inauthentic literary texts.

2) Evaluating the degree to which literary texts are used communicatively based on the application of a set of principles derived from the evaluative criteria.

3) Proposing a set of principles, based on the analysis criteria, that could be applied to facilitate the utilization of a literary text more appropriately.

To meet these objectives, a set of criteria needed to be formed that would assess the use of literary texts for communicative teaching. The current study is not only important for acquiring knowledge about the way literature is used in coursebooks, but it is also useful for exploring the position of literature in current approaches. For this study, the following research questions were addressed:

1) How does the use of authentic and inauthentic texts differ in terms of communicativeness?

2) To what extent are literary texts used communicatively (based on a set of principles derived from evaluative criteria listed below)?

3) Could the set of evaluative criteria used as a tool in this study facilitate the communicative use of literary texts in the ESL/EFL classroom?

\section{Literature Review}

This section discusses and outlines the principles of approaching literary texts to reach a practical solution for assessing the ways in which literary texts are used in communicative language teaching.

\subsection{Communicative Language Teaching}

It was particularly difficult to choose criteria for analyzing the factors enabling communicative use because "there is no one accepted methodology for communicative language teaching" (Cunningsworth, 1995, p. 116). The very broadly defined principles listed below are the ones usually applied:

1) Language is a system for the expression of meaning.

2) The primary function of language is for interaction and communication.

3) The structure of language reflects its functional and communicative uses.

4) The primary units of language are not merely its grammatical and structural features but its categories of functional and communicative meaning (Richards \& Rodgers, 1986, cited in Cunningsworth, 1995, p. 117).

Literature may be seen to fit into these principles in several ways. For instance, the negotiation of meaning is a catalyst for acquisition, as asserted by several theories: Givon's discourse hypothesis (Johnson, 1995, p. 84), Vygotsky's sociocultural theory (Lightbown \& Spada, 1999, p. 44), Long's interaction hypothesis (Johnson, 1995, p. 83), and the cooperative principle (Widdowson, 1984, p. 221). Literature is particularly useful in this respect because "there can be no final reading of a literary text-the meaning is always subject to negotiation" (Brumfit, 1985, p. 106). If they are to be truly communicative, tasks and materials should place more importance "on conveying messages and expressing opinions than on the study of discrete units of language themselves" (Woodward, 2001). Moreover, "prediction, creating a scenario, debating topics on or around a text ... all seem to develop naturally out of [a] literary text" (Long, 1986, p. 58). Many linguists agree that "the keys to approaching a text successfully lie in ... the experience they can bring to making sense of it" (Hedge, 2000, p. 69), and literature can be relevant on two levels: context and theme.

Clearly, "Communicative Language Teaching is best considered an approach rather than a method. It refers to a diverse set of principles" (Richards \& Rodgers, 2001, p. 172). However, there are some factors that enable the communicative use of a text. These are summarized in the checklist below, which is composed of points from different sources. 


\subsection{Criteria for communicative use of literary texts}

\section{Checklist for Enabling Factors}

1) Interaction

a. Is the text relatively open and sufficiently inexplicit in its meanings to allow students to mobilize discussion and debate? (Carter, 1986, p. 115)

2) Student's Role

a. Does the material expect active input from learners? (Cunningsworth, 1995, p. 106)

b. Is additional material provided or are there recommendations for materials for further reading? If so, is guidance provided on how to proceed with these materials? Is there a key for self-monitoring? (Cunningsworth, 1995, p. 106)

3) Authenticity of Task

a. Are tasks real in terms of the real world? (Cunningsworth, 1995, p. 118)

b. Do activities promote the learning of skills and strategies that are transferable to real-life communication? (Cunningsworth, 1995, p. 118)

4) Style and Appropriateness

a. Is there material for sensitizing learners to different levels of appropriateness? (Cunningsworth, 1995, p. 131)

5) Do tasks focus on fluency (meaning) or accuracy (form)? (Littlewood, 1981, p. 1)

\section{Checklist for communicative interactions}

1. Does the task involve a negotiation of meaning? Does it lead the learner to engage in language use as a dynamic problem-solving activity? (Widdowson, 1984, p. 227) Activities that include a negotiation of meaning are as follows:

(a) Information-gap activity, which involves a transfer of given information from one person to another and generally calls for the decoding or encoding of information from or into language.

(b) Reasoning-gap activity, which involves deriving some new information from given information through the processes of inference, deduction, practical reasoning, and the perception of relationships or patterns.

(c) Opinion-gap activity, which involves identifying and articulating a personal preference, feeling, or attitude in response to a given situation. (Prabhu, 1987, cited in Hedge, 2000, p. 58)

2. Does the task allow the reader to be engaged at the discourse level and to infer, anticipate, adjust, and interpret? (Widdowson, 1984, p. 171)

3. Does the task relate to and engage attributes such as knowledge, attitudes, and experience? (Cunningsworth, 1995, p. 86)

\section{Methodology}

The study follows a qualitative research design where content analysis of literary texts is applied. The data used is based on the work of Al-Saeed and Alenezi's (2020) study, in which the content of 44 mainstream EFL coursebooks (see Appendix A) was analyzed. The coursebooks were used between 2015 and 2019, and some of them are being used currently in higher educational institutions in Kuwait and colleges internationally. The article revealed that in these 44 coursebooks, only 25 literary texts (12 inauthentic and 13 authentic) were found. The current study was in part guided by these findings in the 44 coursebooks. For the purposes of this study, the researchers particularly analyzed the way in which the tasks used the texts for communicative teaching according to a set of evaluative criteria based on the principles in literature from the communicative methodology. The findings were recorded in tables, compared, and presented in bar charts.

\section{Findings and Discussion}

\subsection{Literature and Communicative Methodology}

This analysis examined communicativeness in relation to works of literature as texts, applying factors enabling their communicative use. Twenty-five texts were analyzed, and the results were divided into two categories, authentic texts and inauthentic texts (Figures 1 and 2). 


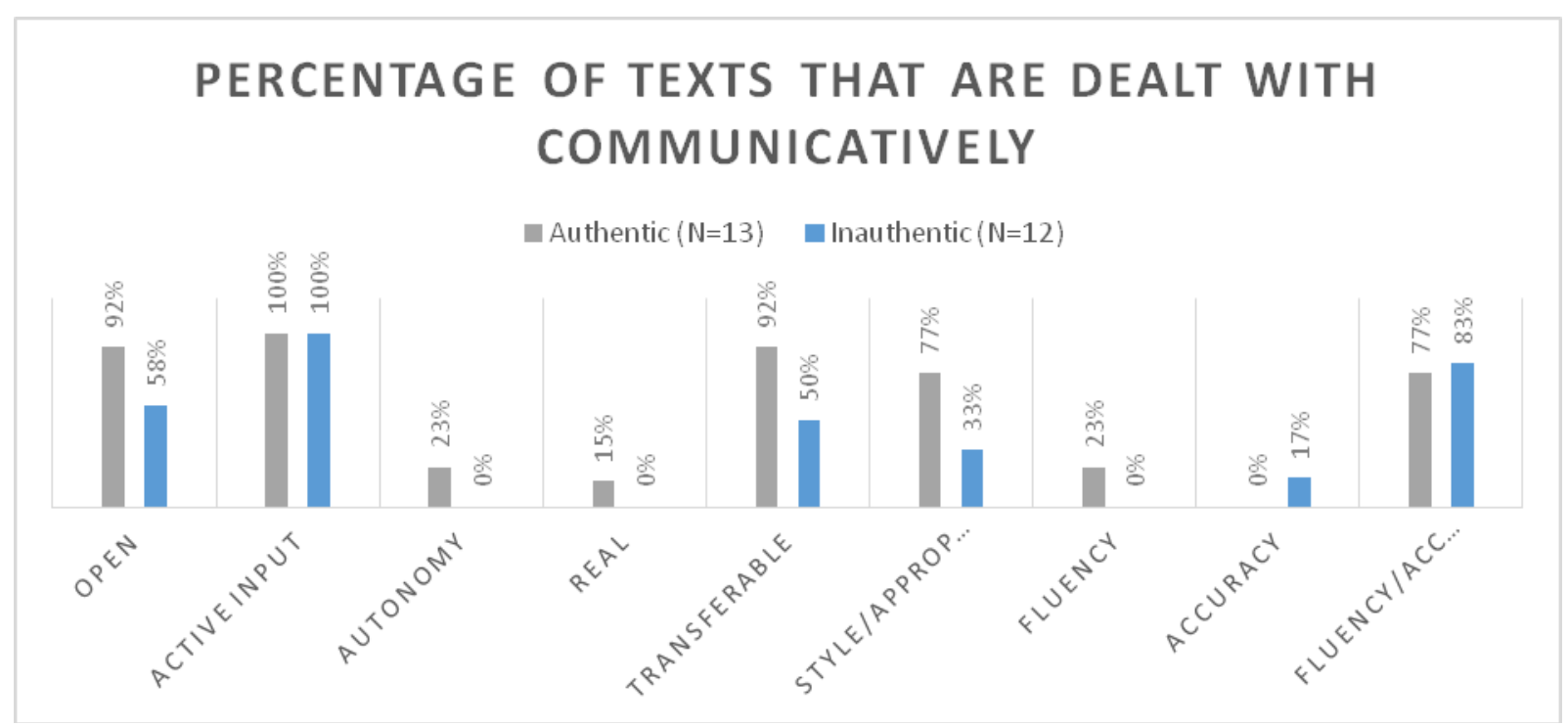

Figure 1. The bar chart clearly shows that although there are some similarities between authentic and inauthentic texts, authentic texts lend themselves better to communicative language use. They are more likely to promote autonomy, as well as provide a more realistic learning situation. It is also clear that inauthentic texts lead to a focus on accuracy, whereas authentic texts lead to a focus on fluency.

Figure 1 shows the percentage of texts that give the learner a positive role (i.e., active input, autonomy), use the texts authentically (i.e., are real, are transferable to real life), sensitize learners to style and appropriateness, and focus mainly on fluency or accuracy.

\subsection{Students' Role}

First, because the student's role is central in communicative methodology, the tasks were evaluated as positive if they called for active input from the learner and encouraged autonomous learning. As shown in Figure 1, both authentic and inauthentic texts sought active input from learners. Such a task, for example, asked students to think of a book they have read or a film they have seen and then engage in a speaking activity about the book or film.

The second role concerned autonomy. The results for this feature were not as positive as for the previous criterion. The authentic texts did to some extent $(23 \%$ of the texts) encourage autonomous learning. The inauthentic texts did not encourage autonomous learning. In the examples found, three types of autonomy were seen: self-assessment, reading for pleasure, and learning strategies. This result may reflect how the learner was viewed in each of the environments; one context could be considered flexible and empowering, whereas another context could be considered more rigid and controlling (i.e., the aim was not to develop a capacity that would be useful in the long term but, rather, to get to a certain level as quickly as possible).

\subsection{Authenticity}

Another aspect that contributes to communicativeness is authenticity. This can mainly be judged by whether the tasks imitate to some extent real-world behavior or enhance skills that are transferable to real life. One example is extensive reading, the purpose of which is "to 'flood' learners with large quantities of L2 input with few or possibly no specific tasks to perform on this material" (Hafiz \& Tudor, 1989, p. 5, cited in Hedge, 2000, p. 221). Intensive reading is useful for strategy training, whereas extensive reading gives "substantial practice in operating these strategies" (Hedge, 2000, p. 202). It has been proven that "incidental vocabulary acquisition can take place through extensive reading ... when no instruction was provided" (Ellis, 1999, p. 36). Furthermore, because communicative methodology seeks to incorporate genuine language uses in its syllabus, then reading for pleasure should have a place. Unfortunately, this is not reflected in the coursebooks, despite the availability of standard exercises such as Scott's (1983) 'Exercise types for EAP comprehension'. The results again indicate the better methodology employed by the coursebooks that included authentic texts. Examples are tasks that involved short stories to be read for pleasure, allowing for a more natural reading.

Furthermore, the second category, the teaching of skills transferable to real life, highlights major differences 
between the two categories of texts. This suggests that coursebooks that valued texts as literature also treated them as literature, whereas coursebooks that had inauthentic texts viewed the texts as language resources. There seems to be three main ways in which texts are utilized to mimic real life:

1) Reading for pleasure (extensive reading): This category is important because an integral part of reading literature is reading it individually and developing a personal response to it. The only series that seemed to do this well was Mosaic.

2) Making literature-literature or literature-life connections: This aspect is important because real readers usually make connections with other literary texts or with life. For literature-life connections, literature is contrasted with texts used in everyday life or students are asked to refer to their own experiences in relation to a text. Examples from my data included extracts presented in conjunction with an article that reflected the texts' theme. Another example asked students to use their own experience of the topic as their subject matter. For literature-literature connections, different literary works were compared.

3) Dealing with a text naturally: This may be achieved by asking questions that real readers would ask, such as "How did you feel when reading this text? Did it amuse you?" This rarely occurred, and when it did, it was not emphasized; hence, it was not included in the results of this study. Another way to deal with a text naturally is through a real task such as retelling a story.

\subsection{Style and Appropriateness}

Another aspect included was that of style and appropriateness. It is important to make a distinction between this category and the second of Littlewood's levels. The language of a literary work as explained by Littlewood (1986) can be divided into five perspectives. The second perspective deals with language as a specific stylistic variety. It is concerned with literature as "a vehicle for the learning of differences between language varieties" ( $p$ 179). (This distinction is important because literary style is accounted for in the analysis of the levels. Only the elements of style not specific to literature will be included here.) This is especially relevant because literature makes extra use of stylistic variation. Tasks should promote the awareness "of the social meaning of language forms .... to use generally acceptable forms and avoid potentially offensive ones" (Littlewood, 1981, p. 6). Literature is ideal for developing this ability because it provides "discourse in which the parameters of the setting and role relationship are defined ... there is a basis for determining why a particular form is used" (McKay, 1986, p. 191). This potential is overlooked in inauthentic texts. In authentic texts, examples of this are formality, register or social rank, and the status of texts as modern or old-fashioned.

\subsection{Fluency and Accuracy}

It is necessary to determine whether a text focuses mainly on fluency or accuracy, or both, because the communicative approach "pays systematic attention to functional as well as structural aspects of language" (Littlewood, 1981, p. 1). If we are to refer to the analysis of Littlewood's perspectives, this may be linked to a balanced approach to the levels; although a complete focus on fluency is more authentic and realistic for native speakers reading their L1, it is not so in the EFL context. Once again, the results show that authentic texts are used more communicatively; the focus of the tasks is spread among mainly fluency, or both accuracy and fluency simultaneously.

The second group of findings shows the percentage of tasks that involved learners in a negotiation of meaning (i.e., information, opinion or reasoning gap), engaged them on a discourse level, or related the text to learners on a personal level.

\subsection{Negotiation of Meaning}

For the elicited interactions to be communicative, they should include some elements of genuine communication, namely, the negotiation of meaning, which could involve the expression of opinions and feelings, the passing on of real information, or reasoning. This provides learners with a chance to produce their own discourse and be exposed to the unpredictability of normal conversation. 


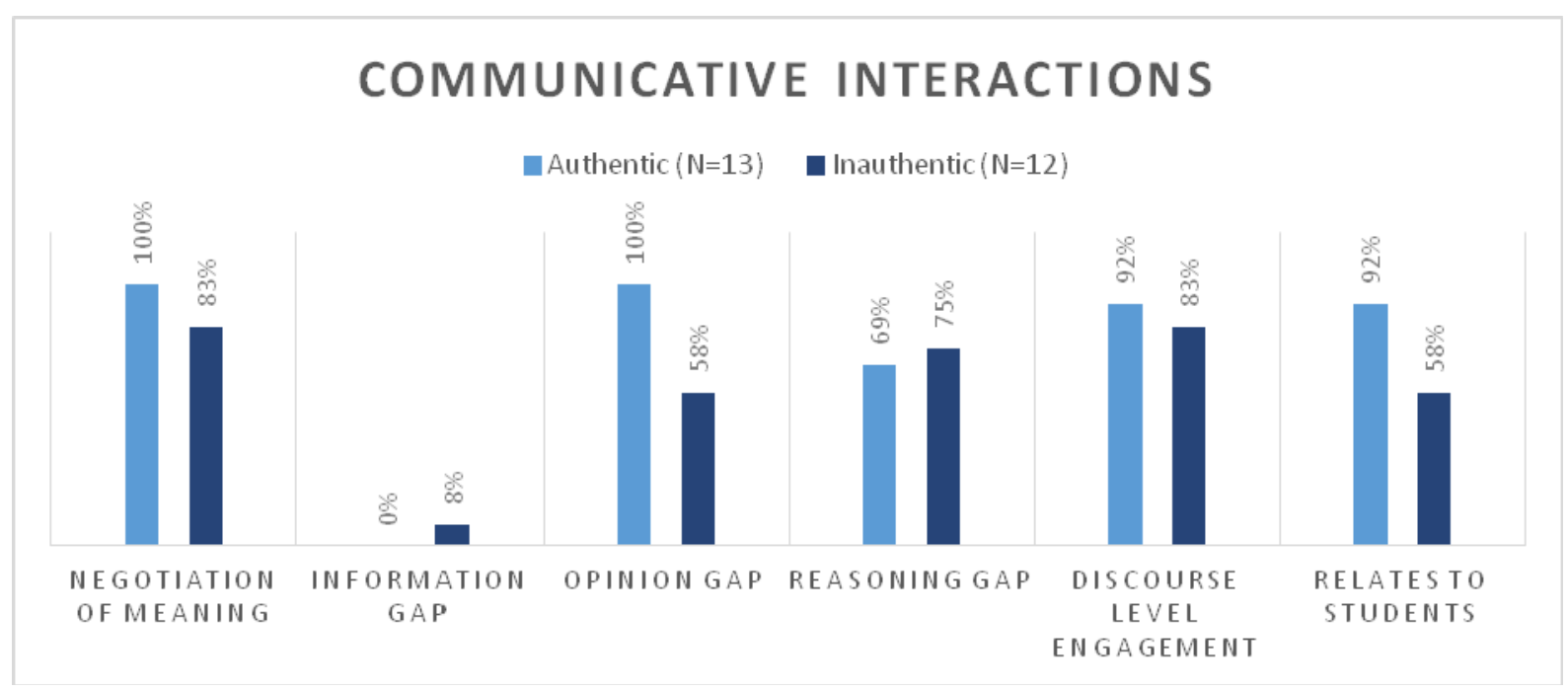

Figure 2. The chart shows that authentic texts promote the negotiation of meaning and stimulate the genuine expression of opinion. They also give the reader more opportunities to relate to the text on a personal level.

Overall, the findings confirmed that authentic texts encourage the use of communicative interactions.

- Opinion gap: This is the most relevant type of negotiation to the study of literature, because literature is valued for the personal response it generates. There is a significant difference between the results for authentic and inauthentic texts. The tasks involve discussion and groupwork or pair work in the negotiation of meaning. Opinion-gap tasks concerned the characters in the texts and how the students related to them. They also concerned general opinions triggered by underlying themes of the texts.

- Information gap: This form of negotiation is important in communicative language teaching but is not as relevant to literary texts as are opinions. Unsurprisingly, it is used more for inauthentic texts. Examples of this seemed to be personal experiences, knowledge, or skills.

- Reasoning gap: This seemed to be a popular form of negotiation because it goes beyond the mere passing on of new information (which is difficult because all of the students were reading the same text) to "deriving some new information from given information" (Hedge, 2000). In some cases, the reasoning gap involved predicting, but in other cases, it involved inference and reasoning.

\subsection{Discourse Level Engagement}

With regard to the promotion of engagement at a discourse level, the results suggest that the texts tended to encourage this equally. In order to fulfill this criterion, texts must encourage inference, anticipation, adjustment, or interpretation. Inference involves making deductions logically from previous information; anticipation involves prediction through the activation of schemata; adjustment involves correcting the predictions anticipated in light of new information; and interpretation involves making a personal judgment on the discourse that goes beyond inference to reading between the lines using a person's individual set of schemata.

\subsection{Relates to Students}

Tasks should be individualized to elicit a genuine personal response by having a relationship to students' lives, personal experiences, and attitudes. Involving each student on different levels is a fundamental part of communicative methodology, especially in the case of literature because reading it is a very individualized process. This may refer to the importance of eliciting opinions, as well as the authenticity of literature-life connections. As for the results, there was a significant difference between the two groups, and this may suggest that authenticity does have an effect on this criterion. The lack of these questions makes coursebooks less interactive and more detached. Allowing students to talk about themselves and their experiences in connection to the texts read may make them more passionate about what they are saying and more eager to negotiate and discuss.

\section{Conclusion}

The study was set to investigate the use of literary texts found in 44 popular EFL coursebooks for 
communicative use in language teaching. Various principles were explored to determine the criteria for scrutinizing the texts. The analysis has shown that authentic and inauthentic literary texts are used differently, and that the former lend themselves to greater communicative usage. Contrary to common belief, literary texts provide great opportunities for communicative use and offer a unique contribution to the EFL classroom that other authentic texts cannot match. The study proposed a set of principles that would enable the utilization of a literary text more appropriately. The criteria proposed in this study proved to be effective as an evaluative tool. It also has the potential to be used to adapt tasks to facilitate the communicative use of literary texts. The findings shed light on how literary texts are currently used, as well as made recommendations on how literature can be used communicatively and be better utilized in coursebooks.

Before defining recommendations, a few limitations of the study should be highlighted. The main limitation relates to the fact that the examined coursebooks were published between the years 2015 and 2019 and the selected titles were those available in the Kuwaiti bookstores.

Furthermore, while the study explored certain principles to suggest a tool for assessing the texts, this is not to advocate these are the only available principles, but the study is limited to the suggested ones.

\section{Recommendations}

- It is important to use literature in a systematic way because it is believed that its teaching "has lacked a consistent methodology for presentation to non-native speakers" (Long, 1986, p. 42). The evaluative criteria in this study may be used as a set of principles that suggest ways in which literary texts can be effectively employed in the classroom.

- It would be useful to conduct follow-up research to garner perception data from teachers and students regarding their views on using literary texts in the ESL classroom. The findings could help to provide more insight into the current position of literature in this context, as well as point to ways to improve learning and disperse negative associations between literature and second language teaching.

- Another important aspect is coursebook designers' views on this matter. Although it would be difficult to gather such data, having it would provide very valuable insights into this issue, as well as pave the way toward improving the current learning situation.

\section{References}

Al-Saeed, S., \& Alenezi, A. (2020). The Use of Literary Texts in EFL Coursebooks: An Exploratory Study. English Language and Literature Studies, 10(3) 86. https://doi.org/10.5539/ells.v10n3p86

Ali, S., Ali, I., \& Hussain, S. (2021). The Effect of Literary Text on the Pragmatic Competence and Fluency of ESL Learners. Sir Syed Journal of Education \& Social Research, 4(1) 148-157. https://doi.org/10.36902/sjesr-vol4-iss1-2021(148-157)

Ashrafuzzaman, M., Ahmed, I., \& Begum, M. (2021). Learning English language through literature: Insights from a survey at university level in Bangladesh. Journal of Language and Linguistic Studies, 17(2), 1190-1209. https://doi.org/10.17263/jlls.904150

Brumfit, C. (1985). Language and Literature Teaching: From Practice to Principle. Oxford: Pergamon Press.

Cunningsworth, A. (1995). Choosing Your Course Book. Oxford: Heinemann.

Ellis, R. (1999). Learning a Second Language through Interaction. Philadelphia/USA: John Benjamins. https://doi.org/10.1075/sibil.17

Gumusok, F. (2013). A Quest for Literature in Elt Coursebooks. Journal of History Culture and Art Research, 2(2). https://doi.org/10.7596/taksad.v2i2.241

Hedge, T. (2000). Teaching and Learning in the Language Classroom. Oxford: Oxford University Press.

Imron, A., \& Hantari, W. (2021). How Poetry Improves EFL Learners' Vocabulary through Curriculum-based Dynamic Assessment. Metathesis, 5(1).

Johnson, K. E. (1995). Understanding Communication in Second Language Classrooms. Cambridge: Cambridge University Press.

Khatib, M., Derakhshan, A., \& Rezaei, S. (2011). Why \&why not literature: A Task-Based Approach to Teaching Literature. International Journal of English Linguistics, 1, 213-218. https://doi.org/10.5539/ijel.v1n1p213

Khatib, M., Rezaeai, S., \& Derakhshan, A. (2011). Literature in EFL/ESL Classroom. English Language Teaching, 4(1), 201-208. https://doi.org/10.5539/elt.v4n1p201 
Lightbown, P., \& Spada, N. (1999). How Languages are Learned. Oxford: Heinemann Press.

Lindsay, C., \& Duncan, F. (2004). Teaching Materials: Using Literature in the EFL/ESL Classroom. The Internet TESL Journal, 10(12).

Littlewood, W. (1981). Communicative Language Teaching. Cambridge: Cambridge University Press.

Littlewood, W. (1986). Literature in the School Foreign Language Course. In C. J. Brumfit \& R. A. Carter (Eds.), Literature and Language Teaching. Oxford University Press.

Long, M. (1986). A feeling for Language: The multiple values of teaching literature. In C. J. Brumfit \& R. A. Carter (Eds.), Literature and Language Teaching (pp. 42-59). Oxford University Press.

Mart, C. (2016). The use of literature in language teaching. Journal of Educational and Instructional Studies in the World, 6(2).

McKay, S. (1986). Literature in the ESL Classroom. In C. J. Brumfit \& R. A. Carter (Eds.), Literature and Language Teaching. Oxford University Press.

Richards, J. C., \& Rodgers, T. S. (2001). Approaches and Methods in Language Teaching. Cambridge University Press. https://doi.org/10.1017/CBO9780511667305

Scott, M. (1983). Exercise-Types for EAP Comprehension. The Especialist, 7, 17-44.

Teranishi, M. et al. (2015). Literature and Language Learning in the EFL Classroom. https://doi.org/10.1057/9781137443663

Violetta-Irene, K. (2015). The use of literature in the language classroom: Methods and aims. International Journal of Information and Education Technology, 5(1), 74-79. https://doi.org/10.7763/IJIET.2015.V5.479

Vural, H. (2013). Use of Literature Motivation in ELT Classes. Mevlana International Journal of Education (MIJE), 3(4), 15-23. https://doi.org/10.13054/mije.13.44.3.4

Widdowson, H. G. (Ed.). (1984). Explorations in Applied Linguistics. Oxford University Press.

Woodward, T. (2001). Planning Lessons and Courses. Cambridge University Press. https://doi.org/10.1017/CBO9780511732973

\section{Appendix A}

\section{Coursebooks that are used in the research as listed in Al-Saeed and Alenezi's (2020) study.}

\section{Coursebooks which included literary texts}

1 New Headway Plus pre-intermediate

Oxford (2006)

2 New Headway Plus intermediate

Oxford (2006)

3 New Headway pre-intermediate

Oxford (2007)

4 New Headway Plus upper intermediate

Oxford (2009)

5 New Headway Plus elementary

Oxford (2013)

6 College Reading 2

Heinle Cengage Learning 2006

7 Empower upper intermediate

Cambridge university press 2015

8 Mosaic Reading 1

McGraw Hill (2014)

9 Mosaic Reading 1 
McGraw Hill (2014)

10 New language leader Pre-intermediate

Pearson (2014)

\section{Coursebooks which did not include literary texts}

1 New Headway Plus beginner

Oxford (2013)

2 Unlock reading and writing skills 1

Cambridge University Press (2014)

3 Unlock reading and writing skills 2

Cambridge University Press (2014)

$4 \quad$ Unlock reading and writing skills 3

Cambridge University Press (2014)

5 Unlock reading and writing skills 4

Cambridge University Press (2014)

6 English Unlimited 1

Cambridge University Press (2015)

7 English Unlimited 2

Cambridge University Press (2015)

8 Read This! 1

Cambridge University Press (2010)

9 Read This! 2

Cambridge University Press (2010)

10 Read This! 3

Alice Savage

Cambridge University Press (2010)

11 Interchange Intro

Cambridge University Press (2017)

12 Interchange 1

Cambridge University Press (2017)

13 Interchange 2

Cambridge University Press (2013)

14 Interchange 3

Cambridge University Press (2013)

15 Well Read 1

Oxford university press (2008)

16 Well Read 2

Oxford university press (2008)

17 Language Leader Elementary

Pearson Longman (2008)

18 Language Leader Pre-intermediate

Pearson Longman (2008)

19 Language Leader Intermediate 
Pearson Longman (2008)

20 Interactions Access Reading and Writing

McGraw Hill (2012)

21 Interactions 1 Reading

McGraw Hill (2015)

22 Interactions 2 Reading

McGraw Hill (2015)

23 Starting skills 1

Garnet Education 2010

24 Touchstone 1

Cambridge University Press and Obeikan (2012)

25 Touchstone 2

Cambridge University Press and Obeikan (2009)

26 Touchstone 3

Cambridge University Press and Obeikan (2012)

27 Touchstone 4

Cambridge University Press and Obeikan (2012)

28 Q: Skills for Success Reading and Writing Intro

Oxford University Press (2016)

29 Q: Skills for Success Reading and Writing 1

Oxford University Press (2016)

30 Q: Skills for Success Reading and Writing 2 Oxford University Press (2016)

31 Q: Skills for Success Reading and Writing 3

Colin S. Ward and Margot F. Gramer

Oxford University Press (2016)

32 Q: Skills for Success Reading and Writing 4

Debra Daise and Charl Norlioff

Oxford University Press (2016)

33 Pathways 1

National Geographic Learning and Heinle Cenage (2013)

34 Headway academic skills introductory level

Oxford University Press and Oxford (2018)

\section{Copyrights}

Copyright for this article is retained by the author, with first publication rights granted to the journal.

This is an open-access article distributed under the terms and conditions of the Creative Commons Attribution license (http://creativecommons.org/licenses/by/4.0/). 